Prepared in cooperation with the

St. Johns River Water Management District

\title{
A Method for Simulating Transient Ground-Water Recharge in Deep Water-Table Settings in Central Florida by Using a Simple Water-Balance/Transfer-Function Model
}

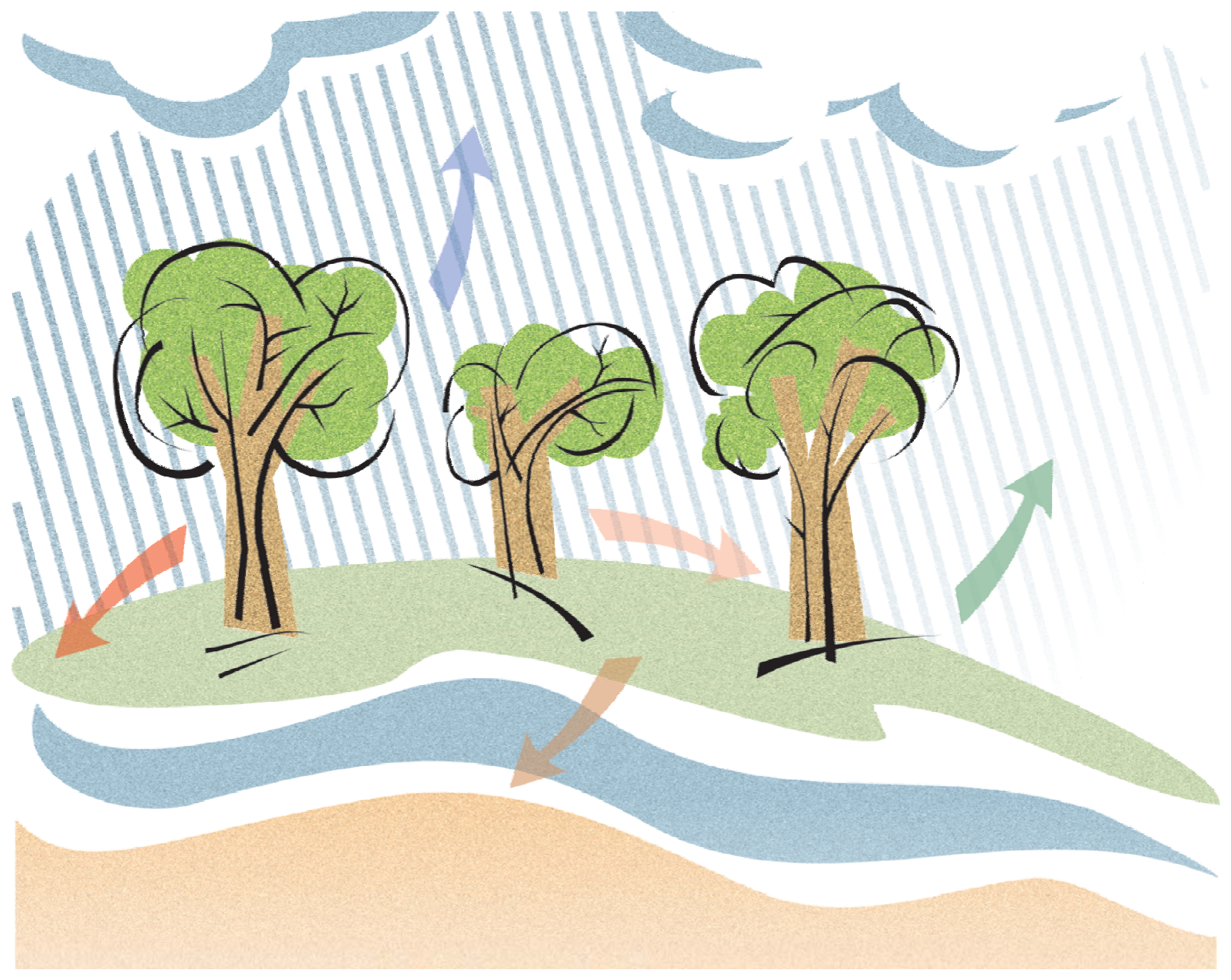

Scientific Investigations Report 2004-5195 